\begin{tabular}{cc|c}
\hline Tar. Bil. Der. & Journal of Agricultural Sciences \\
& $\begin{array}{c}\text { Dergi web sayfası: } \\
\text { www.agri.ankara.edu.tr/dergi }\end{array}$ & Journal homepage: \\
& www.agri.ankara.edu.tr/journal
\end{tabular}

\title{
Effect of Different Vane Combinations on Fertilizer Distribution Uniformity with Various Flow Rates in Spinning Disc Broadcasters
}

\author{
Yıldıran YILDIRIMa ${ }^{\mathrm{a}}$, Mazhar KARA ${ }^{\mathrm{a}}$ \\ ${ }^{a}$ Atatürk University, Faculty of Agriculture, Department of Agricultural Machinery, Erzurum, TURKEY
}

\section{ARTICLE INFO}

Research Article - Agricultural Technologies $\quad$ DOI: 10.1501/Tarimbil_0000001192

Corresponding author: Yildıran YILDIRIM, e-mail: yildiran@atauni.edu.tr, Tel: +90(442) 2312550

Received: 23 January 2012, Received in revised form: 05 March 2012, Accepted: 13 March 2012

\begin{abstract}
Vanes throwing the particles of fertilizer or granular material onto a field are one of the most important machine parts influencing the fertilizer distribution pattern in spinning disc broadcasters. Manufacturers prefer mostly straight-shaped vanes in spinning disc broadcasters, probably because their production is easy. In previous studies, therefore, many researchers studied the spinning disc broadcaster with the straight-shaped vanes only. In this study, the effect of the combinations of the straight-shaped vane with different shaped vanes on the fertilizer distribution uniformity in single-spinning disc broadcaster was investigated with various flow rates using triple superphosphate. The combinations used in the study were the straight-shaped vane in combination with forward-curved-5, forwardcurved-10, back-curved-5, and back-curved-10 vane, and "no combination" consisted of the straight-shaped vane only. The circular orifices of 30, 40 and $50 \mathrm{~mm}$ diameters were used at the bottom of hopper to obtain the different flow rates of the fertilizer. The results of the study showed that the combination of the different shaped vanes on the spinning disc had a significant effect on fertilizer distribution uniformity. "No combination" used commonly in practice did not give the best fertilizer distribution uniformity. The best fertilizer distribution uniformity was obtained from the combination of the straight-shaped vane with forward-curved-5 vane shape for all the flow rates. The CV values obtained from this combination were $10.31 \%, 15.49 \%$, and $19.92 \%$ for the orifices with diameters of 30, 40 and $50 \mathrm{~mm}$, respectively.
\end{abstract}

Keywords: Vane shape; Distribution uniformity; Fertilizer broadcaster; Distribution pattern; Flow rate

\section{Diskli Dağıtma Makinalarında Farklı Kanat Kombinasyonlarının Değişik Debilerde Gübre Dağılım Düzgünlüğüne Etkisi}

\section{ESER BILGISII}

Araştırma Makalesi - Tarım Teknolojileri

Sorumlu Yazar: Yıldıran YILDIRIM, e-posta: yildiran@atauni.edu.tr, Tel: +90(442) 2312550

Geliş tarihi: 23 Ocak 2012, Düzeltmelerin gelişi: 05 Mart 2012, Kabul: 13 Mart 2012

\section{ÖZET}

Taneli materyali ya da kimyasal gübreyi tarlaya firlatan kanatlar, diskli gübre dağıtma makinalarında gübre dağılım desenini etkileyen en önemli makina parçalarından biridir. İmalatçılar muhtemelen üretimleri kolay olduğu için, 
diskli gübre dağıtma makinalarında çoğunlukla düz şekilli kanatları tercih etmektedirler. Bundan dolayı, önceki çalışmalarda, çoğu araştırmacı sadece düz şekilli kanatlara sahip diskli gübre dağıtma makinalarını incelemişlerdir. Bu çalışmada, farklı şekilli kanatlar ile düz şekilli kanat kombinasyonlarının triple süper fosfat gübresi kullanarak, değişik debilerde gübre dağılım düzgünlüğü üzerine etkisi incelenmiştir. Araştırmada ileri bükük-5, ileri bükük-10, geri bükük-5, geri bükük-10 kanatlar ile düz şekilli kanadın oluşturduğu kombinasyonlar ve sadece kombinasyon oluşturmayan düz kanatlar kullanılmıştır. Farklı gübre debileri elde etmek amaciyla depo tabanında 30, 40 ve 50 mm çaplarında daire şeklindeki çıkış delikleri kullanılmıştır. Araştırma sonuçları, dağıtıcı disk üzerindeki farklı şekilli kanat kombinasyonlarının gübre dağılım düzgünlüğü üzerinde önemli bir etkisinin olduğunu göstermiştir. Uygulamada yaygın olarak kullanılan ve sadece düz kanattan oluşan kombinasyonsuz seçeneği en iyi gübre dağılım düzgünlüğünü sağlamamıştır. Bütün gübre debilerinde, en iyi gübre dağılım düzgünlüğü ileri bükük-5 kanat ile düz kanadın oluşturduğu kombinasyondan elde edilmiştir. Bu kombinasyondan elde edilen CV değerleri, 30, 40 ve 50 mm çıkış deliği çapları için sırasıyla, \%10.31, \%15.49 ve \%19.92 olarak belirlenmiştir.

Anahtar sözcükler: Kanat şekli; Dağılım düzgünlüğü; Gübre dağıtma makinası; Dağılım deseni; Debi

(C) Ankara Üniversitesi Ziraat Fakültesi

\section{Introduction}

Spinning disc broadcasters have widely been used in Turkey due to their simple construction, economical price and effectiveness. For instance, the number of spinning disc broadcasters in use has reached 366,781 in the year of 2010 in Turkey, increasing $23.19 \%$ for the last decade (TÜİK 2011).

One of the most important parameters which affect the distribution uniformity in spinning disc broadcasters is the flow rate of fertilizer on spinning disc. The previous studies showed that the uniformity of fertilizer distribution decreased as the flow rate increased (Carman 1992; Parish 2002; Yildirim \& Kara 2003; Yildirim 2006a \& b; Yildirim \& Ozturk 2007). Çarman (1991), Olierslagers et al (1996), and Yildirim (2006a \& b) reported that the fertilizer distribution pattern was better when the revolution speeds of spinning disc for higher flow rates of the fertilizer was increased with straight vanes with no combinations. Yildirim \& Kara (2003) determined that the fertilizer distribution evenness became better when the vane height was increased for high flow rates.

The design properties of vane on spinning disc have important effects on fertilizer distribution patterns in spinning disc broadcasters. The vane properties such as height, shape, position on disc, and profile type have the important effects on the distribution uniformity of the fertilizer in spinning disc broadcasters (Özmerzi 1974; Erol \& Özmerzi
1977; Önal \& Tozan 1984; Yetkin \& Çarman 1988; Yildirim \& Kara 2003; Özbek et al 2006; Yildirim 2008a). The vanes used on spinning discs can be straight, curved or composite-shaped (Srivastava et al 1993). However, the vanes except straight-shaped ones are not mostly produced by manufacturers. The reason for this may be the ease of the straight-shaped vanes. Also, manufacturers do not primarily use the combination of the different shaped vanes on spinning disc. For this reason, in previous studies, many researchers studied the spinning disc broadcaster with the straight-shaped vanes only.

A few researchers studied on the different shapes of vane. Yildirim (2008a) investigated the effect of the different vane shapes on the fertilizer distribution pattern using triple superphosphate and calcium ammonium nitrate with the single flow rate in single spinning disc broadcasters. The author used the forward-curved-5, forwardcurved-10, back-curved-5, back-curved-10, and straight vane on a flat disc in a radial position. The author determined that the best and worst distribution patterns for both triple superphosphate and calcium ammonium nitrate were obtained from the forward-curved-5 and forward-curved-10 vane shape, respectively. Parish (2003a) investigated five commercial walkbehind spinning disc broadcasters to evaluate the ability of pattern correction systems. Three of these broadcasters had the straight vanes only with flat disc, one of these consisted of the straight vane with concave-shaped spinning disc, 
and the other had a vane combination with two straight and two curved vanes on a flat spinning disc. All of these broadcasters had four vanes on their own discs. According to the results of the study, the best distribution pattern was obtained from broadcaster with vane combination with two straight and two curved vanes. However, these machines were different from each other in terms of the spinning disc height $(27.9$ to $36.2 \mathrm{~cm})$, spinning disc diameter (22.9 to $30.5 \mathrm{~cm})$, spinning disc shape (concave, flat), rotational speeds of disc (336 to $412 \mathrm{~min}^{-1}$ for $4.8 \mathrm{~km} \mathrm{~h}^{-1}$ ) metering port shapes and configurations, and mechanisms of discharging of fertilizer through ports. Consequently, it is not clear highly unlikely that the best distribution pattern is only obtained due to the vane combination with two straight and two curved vanes. Hence, the combination of the different shaped vanes should be investigated on the same fertilizer broadcaster to focus on the effect of vane combinations on the fertilizer distribution pattern. Furthermore, the effect of the different vane combinations under the influence of the different flow rates of fertilizer on the uniformity of the fertilizer distribution was not evaluated in previous studies.

The objective of this study was to determine the effect of the different vane combinations on the fertilizer distribution pattern and the vane combination giving the best distribution uniformity for the various flow rates of the fertilizer.

\section{Materials and Methods}

Five different vane combinations, including "no combination", were used on the same spinning disc in the study. The vane shapes used in the study were straight, forward-curved, and backcurved. Each of the forward-curved and backcurved vanes was consisted of two different types as shown in Figure 1. "No combination" was consisted of the straight vanes only. The six vanes were employed for each combination, including "no combination" on the same spinning disc. The shapes, dimensions, positions, and top view of combination of the vanes used in the study are

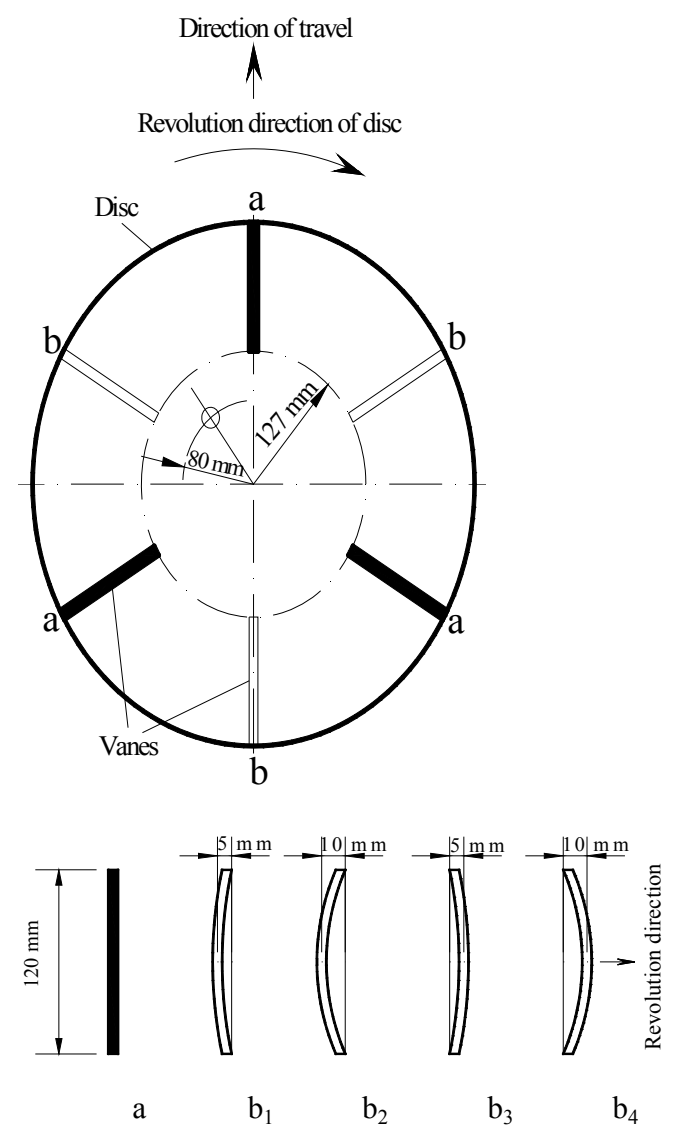

Figure 1-The top view of the vanes and disc used in the study (a: Straight $(S), b_{1}$ : Forward-curved5 (FC-5), $b_{2}$ : Forward-curved-10 (FC-10), $b_{3}$ : Back-curved-5 (BC-5), $b_{4}$ : Back-curved-10 (BC10))

Şekil 1-Çalışmada kullanılan disk ve kanatların üstten görünüşü ( $a$ : Düz (S), $b_{1}$ : Illeri bükük-5 (FC5), $b_{2}$ : Illeri bükük-10 (FC-10), $b_{3}$ : Geri bükük-5 (BC-5), b4: Geri bükük-10 (BC-10))

shown in Figure 1. All vanes made of sheet metal had the height of $65 \mathrm{~mm}$ and the thickness of 2 $\mathrm{mm}$, and they were mounted in radial position on a flat spinning disc with $500 \mathrm{~mm}$ diameter. Three of the six vanes in each combination were the straight-shaped, and the other three were different shaped in accordance with combination used (Figure 1). The distance between the center of 
spinning disc and the inner end of vanes on the disc was $127 \mathrm{~mm}$ (Figure 1). As it is seen in the Figure 1, the vane combinations used in the study were arranged as $a \times b_{1}, a \times b_{2}, a \times b_{3}$, and $a \times b_{4}$.

Triple superphosphate was used in the study. The values of sieve analysis, bulk density, repose angle, and moisture content of the fertilizer are shown in Table 1. The circular orifices with diameters of 30,40 and $50 \mathrm{~mm}$ at the bottom of the conical fertilizer hopper were used for obtaining various flow rates. The flow rates obtained from these orifices are 9.32, 24.58 and $48.09 \mathrm{~kg} \mathrm{~min}^{-1}$, respectively. The distance between the centers of all orifices used in the study and the center of the spinning disc, known as feed radius, was $80 \mathrm{~mm}$. The feed radius did not change as the orifice diameter was increased because the orifices were circular shaped.

Pattern tests for all vane combinations including "no combination" with the various flow rate of the fertilizer were conducted and the coefficients of variation (CV) based on the sideby-side circuitous mode of operation were calculated according to ASAE S341.2 (ASAE Standards, 1998). Prior to the replicated tests, the optimized patterns that minimized skewing from side to side for each orifice diameter and vane combination were obtained by shifting the angular position of the dropping of the fertilizer on disc, and then the optimized patterns were replicated three times.

The spinning disc was level and the height from the top of collection trays was $650 \mathrm{~mm}$ during the tests. The single-spinning disc broadcaster operated with a power take-off (PTO) speed of $540 \mathrm{~min}^{-1}$ was moved over the collection trays along the same centerline at a speed of 5.8 $\mathrm{km} \mathrm{h}^{-1}$. One tray was omitted on each side of the center to allow the tractor wheels to pass through the collection trays during tests. The fertilizer rates at the locations without tray were interpolated from the adjacent collection trays (Parish 2003b). The arrangement on the testing area, dimensions and shape of collection trays were the same with those of Yildirim $(2008 \mathrm{a} \& \mathrm{~b})$.
Table 1-Physical properties of triple superphosphate

Çizelge 1-Triple süperfosfatın fiziksel özellikleri

\begin{tabular}{lc}
\hline \multicolumn{1}{c}{ Sieve Fraction } & \% retained on sieve \\
\hline$<1.6 \mathrm{~mm}$ & 0.85 \\
$1.6-2.00 \mathrm{~mm}$ & 3.59 \\
$2.00-2.80 \mathrm{~mm}$ & 55.05 \\
$2.80-3.35 \mathrm{~mm}$ & 24.85 \\
$3.35-4 \mathrm{~mm}$ & 14.27 \\
$>4 \mathrm{~mm}$ & 1.39 \\
& \\
Mass median diameter $(\mathrm{mm})$ & 2.74 \\
& \\
Bulk density $\left(\mathrm{kg} \mathrm{m}^{-3}\right)$ & 1157 \\
Moisture content $(\%)$ & 2.51 \\
Repose angle $\left({ }^{\circ}\right)$ & 31.50 \\
\hline
\end{tabular}

\section{Results and Discussion}

Totally 45 optimized distribution patterns were obtained from five vane combinations at three flow rates for triple superphosphate. The values of $\mathrm{CV}$, skewing, and minimum and maximum belonging to the overlapped patterns are shown in Table 2. Typical acceptable levels for these parameters are $\mathrm{CV} \leq 20 \%$, minimum $\geq 80 \%$ of the mean rate, and maximum $\leq 120 \%$ of the mean rate (Parish 2001). In addition to these values, the working width and the range of working width for the distribution patterns with $\leq 20 \mathrm{CV} \%$ are shown in the same table. All data were analyzed by oneway analysis of variance (ANOVA) for each orifice diameter, separately. According to the results of the ANOVA, vane combination had a significant effect $(P<0.05)$ on the $\mathrm{CV}$, skewing, and minimum and maximum values for each orifice diameters (Table 2).

According to the data in Table 2, the best distribution uniformity was obtained from the combination of $\mathrm{S}$ and FC-5 for all the orifice diameters. The minimum $\mathrm{CV}$ values obtained from this combination were $10.31 \%, 15.49 \%$, and $19.92 \%$ for the orifice diameter of 30,40 and 50 $\mathrm{mm}$, respectively. "No combination" consisting of straight-shaped vanes only, mostly common used in practice, did not give the best 
Table 2-Characteristics of overlapped patterns obtained from the different combinations of vane for each orifice diameters ${ }^{[\mathrm{a}]}$

Çizelge 2-Her bir çıkış deliği çapı için farklı kanat kombinasyonlarından elde edilen örtmeli desenlerin özellikleri

\begin{tabular}{|c|c|c|c|c|c|c|c|}
\hline $\begin{array}{c}\text { Orifice } \\
\text { diameter }(\mathrm{mm}) \\
\text { / Flow rate } \\
\left(\mathrm{kg} \mathrm{min}^{-1}\right) \\
\end{array}$ & $\begin{array}{l}\text { Vane } \\
\text { combination }^{[\mathrm{b}]}\end{array}$ & $\begin{array}{l}\mathrm{We}^{[\mathrm{c}]} \\
(\mathrm{m})\end{array}$ & $\begin{array}{c}\text { Range of } \\
\text { working width }^{[\mathrm{d}]} \\
\text { (m) }\end{array}$ & $\begin{array}{l}\mathrm{CV}^{[\mathrm{e}]} \\
(\%)\end{array}$ & $\begin{array}{c}\text { Skewing }^{[\mathrm{f}]} \\
\text { (\%Left/\%Right) }\end{array}$ & $\begin{array}{c}\operatorname{Min} .{ }^{[g]} \\
(\%)\end{array}$ & $\begin{array}{c}\operatorname{Max} . \\
(\%)\end{array}$ \\
\hline \multirow{6}{*}{$\begin{array}{l}30 \\
/ 9.32\end{array}$} & No combination & 13.5 & $12.00 \ldots 14.00$ & $17.68 \mathrm{~b}$ & $48 / 52 \mathrm{ab}$ & $76 \mathrm{a}$ & $132 \mathrm{ab}$ \\
\hline & $\mathrm{S}$ and $\mathrm{FC}-5$ & 9 & $08.50 \ldots 11.00$ & $10.31 \mathrm{~d}$ & $47 / 53 \mathrm{~b}$ & $77 \mathrm{a}$ & $116 \mathrm{~d}$ \\
\hline & $\mathrm{S}$ and $\mathrm{FC}-10$ & 10 & ---- & $21.53 \mathrm{a}$ & 49/51 a & $64 \mathrm{~b}$ & $139 \mathrm{a}$ \\
\hline & $\mathrm{S}$ and $\mathrm{BC}-5$ & 9 & $08.50 \ldots 10.50$ & $14.58 \mathrm{c}$ & $45 / 55 \mathrm{c}$ & $75 \mathrm{a}$ & $127 \mathrm{bc}$ \\
\hline & $\mathrm{S}$ and $\mathrm{BC}-10$ & 9 & $08.50 \ldots 10.00$ & $14.44 \mathrm{c}$ & $46 / 54 \mathrm{c}$ & $72 \mathrm{a}$ & $124 \mathrm{c}$ \\
\hline & $\mathrm{LSD}_{0.05}$ & & & 0.8436 & 1.485 & 4.554 & 7.718 \\
\hline \multirow{6}{*}{$\begin{array}{c}40 \\
/ 24.58\end{array}$} & No combination & 11 & $\begin{array}{ll}--- \\
\end{array}$ & $20.60 \mathrm{~b}$ & $43 / 57 \mathrm{c}$ & $71 \mathrm{a}$ & $145 \mathrm{~b}$ \\
\hline & $\mathrm{S}$ and $\mathrm{FC}-5$ & 11 & $08.50 \ldots 13.00$ & $15.49 \mathrm{~d}$ & $45 / 55 b$ & $77 \mathrm{a}$ & $131 \mathrm{c}$ \\
\hline & $\mathrm{S}$ and $\mathrm{FC}-10$ & 12 & ---- & $26.42 \mathrm{a}$ & $43 / 57 \mathrm{c}$ & $69 \mathrm{a}$ & $168 \mathrm{a}$ \\
\hline & $\mathrm{S}$ and $\mathrm{BC}-5$ & 14 & $13.00 \ldots 15.00$ & $18.24 \mathrm{c}$ & $48 / 52 \mathrm{a}$ & $70 \mathrm{a}$ & $137 \mathrm{bc}$ \\
\hline & $\mathrm{S}$ and $\mathrm{BC}-10$ & 12 & $11.50 \ldots 13.00$ & $18.40 \mathrm{c}$ & $46 / 54 b$ & $61 \mathrm{~b}$ & $129 \mathrm{c}$ \\
\hline & $\mathrm{LSD}_{0.05}$ & & & 1.386 & 01.328 & 7.617 & 10.030 \\
\hline \multirow{6}{*}{$\begin{array}{c}50 \\
/ 48.09\end{array}$} & No combination & 15 & ---- & $26.94 \mathrm{~b}$ & $42 / 58 d$ & $66 \mathrm{~b}$ & $164 \mathrm{a}$ \\
\hline & $\mathrm{S}$ and $\mathrm{FC}-5$ & 13 & $13.00 \ldots 14.00$ & $19.92 \mathrm{~d}$ & $45 / 55 \mathrm{a}$ & $63 \mathrm{bc}$ & $140 \mathrm{~d}$ \\
\hline & $\mathrm{S}$ and $\mathrm{FC}-10$ & 8.5 & ---- & $31.10 \mathrm{a}$ & $40 / 60 \mathrm{e}$ & $58 \mathrm{c}$ & $164 \mathrm{a}$ \\
\hline & $\mathrm{S}$ and $\mathrm{BC}-5$ & 14 & ---- & $21.51 \mathrm{c}$ & $44 / 56 \mathrm{~b}$ & $64 \mathrm{bc}$ & $146 \mathrm{c}$ \\
\hline & $\mathrm{S}$ and $\mathrm{BC}-10$ & 13 & ---- & $22.14 \mathrm{c}$ & $43 / 57 \mathrm{c}$ & $73 \mathrm{a}$ & $153 \mathrm{~b}$ \\
\hline & $\mathrm{LSD}_{0.05}$ & & & 1.142 & 0.9401 & 5.830 & 3.728 \\
\hline \multicolumn{8}{|c|}{${ }^{[\mathrm{a}]}$ :Each data point shown is the mean of three replications. } \\
\hline \multicolumn{8}{|c|}{$\begin{array}{l}{[\mathrm{b}] \text { :No combination: the Straight vane only, S: Straight vane, FC: Forward-curved vane, BC: Back-curved vane. }} \\
{[\mathrm{c}]: \text { The effective working width at the minimum CV in overlapped pattern. }} \\
{[\mathrm{d}] \text { :The minimum and maximum working widths at the CV value lower than } 20 \% \text { in overlapped pattern. }} \\
{[\mathrm{e}] \text { :The CV values at width We. }}\end{array}$} \\
\hline
\end{tabular}

distribution pattern. Moreover, this combination had the second worst distribution uniformity for all orifice diameters. The minimum $\mathrm{CV}$ values belonging to "no combination" were $17.68 \%$, $20.60 \%$, and $26.94 \%$ for the orifice diameter of 30, 40 and $50 \mathrm{~mm}$, respectively. "No combination" gave the acceptable CV value $(<20 \%)$ for only the orifice diameter of $30 \mathrm{~mm}$.

The values of $\mathrm{CV}$ increased with increasing diameters of orifice for all of the vane combinations. This finding agrees with that of Yildirim (2006a \& b) and Yildirim \& Kara (2003), who reported that the CV values also increased as increased the orifice diameter. The values of $\mathrm{CV}$ obtained from orifice diameter of 30,40 and $50 \mathrm{~mm}$ ranged from $21.53 \%$ to $14.44 \%$, from $26.42 \%$ to $15.49 \%$, and from $31.10 \%$ to $21.51 \%$, respectively. Only the combination of $\mathrm{S}$ and $\mathrm{FC}-10$ for the orifice diameter of $30 \mathrm{~mm}$ exceeded the acceptable value $(\leq 20 \%)$ of $\mathrm{CV}$, and this combination gave the worst distribution uniformity for all orifice diameters. For diameter orifice of $50 \mathrm{~mm}$ in which the highest flow rate was obtained, only the combination of $\mathrm{S}$ and FC-5 gave the acceptable value of $\mathrm{CV}(\leq 20 \%)$. Therefore, this vane 
combination can be used to obtain acceptable values of $\mathrm{CV}$ for the high flow rate of fertilizer, and so the high application rate of fertilizer on field. The "no combination", used in practice, gave the acceptable values of $\mathrm{CV}$ for only the orifice diameter of $30 \mathrm{~mm}$. Previous studies showed that the fertilizer distribution uniformity became worse as the amount of fertilizer flowing onto spinning disc was increased (Yildirim \& Kara 2003; Yildirim 2006a \& b).

According to Table 2, the values of skewing were significantly different from $50 \%$ Left $/ 50 \%$ Right $(P<0.05)$ at the $95 \%$ level of significance for the orifice diameters of 30, 40 and $50 \mathrm{~mm}$, respectively. Skewing in the overlapped pattern is expressed as the percentage of material on the left side of the pattern centerline compared with the percentage of material on the right side of the pattern centerline. Önal (1995) also reported that the difference between amount of fertilizer on the left side of the pattern centerline and amount of fertilizer on the right side of the pattern centerline (skewing) should be $\leq 4 \%$. The best skewing values obtained from overlapped patterns were $\mathrm{S}$ and FC-10 (49\%Left/51\%Right), $\mathrm{S}$ and BC-5 (48\%Left/52\%Right), and $\mathrm{S}$ and FC-5
(45\%Left $/ 55 \%$ Right), for the orifice diameters of 30,40 and $50 \mathrm{~mm}$, respectively. The most skewing overlapped patterns in Table 2 were $\mathrm{S}$ and BC-5 (45\%Left/55\%Right), "no combination" which was the same with $\mathrm{S}$ and $\mathrm{FC}-10$ (43\%Left $/ 57 \%$ Right), and $\mathrm{S}$ and FC-10 (40\%Left $/ 60 \%$ Right) vane combinations for the orifice diameters of 30,40 and $50 \mathrm{~mm}$, respectively. Figures 2, $3 \& 4$ show the optimized distribution patterns obtained from all vane combinations for each orifice diameters of 30,40 and $50 \mathrm{~mm}$, separately. As is seen in Figures, the optimized distribution patterns had trend in skewing toward the left as the orifice diameter (therefore the flow rate) was increased for all the vane combinations. The reason for this is that the fertilizer leave disc late because of increasing of fertilizer amount on disc with increasing of orifice diameter. This result is similar to the patterns in study of Yildirim \& Kara (2003) and Yildirim (2006a). The high skewing is an important problem to obtain the acceptable values of $\mathrm{CV}$.

There were significant differences in minimum values expressed as percentages of the mean rates in the overlapped patterns. The combination of S and FC-5 vane had the best

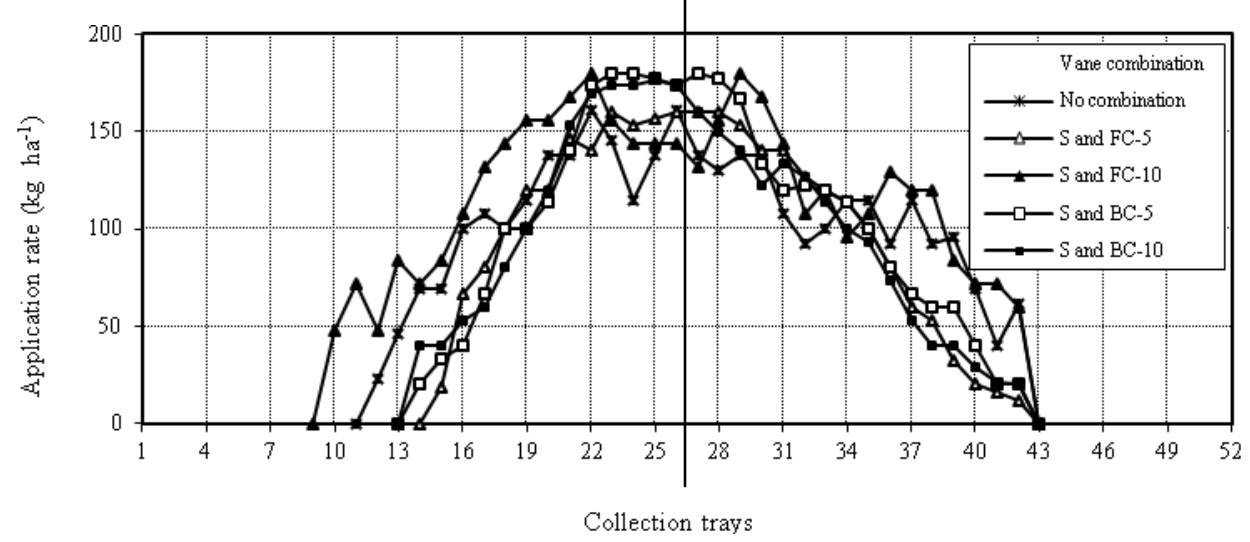

Figure 2-The optimized distribution patterns obtained from the five different combinations of vanes for the orifice diameter of $30 \mathrm{~mm}$. The center of the disc passed midway between the centers of collection trays 26 and 27. Each line is the mean of three replications

Şekil 2. Farklı kanat kombinasyonlarından $30 \mathrm{~mm}$ çapındaki çıkış deliği için elde edilen optimum dağglım desenleri. Disk merkezi 26 ile 27 numaralı toplama kutularının arasından geçmektedir. Grafik çizgilerinin her biri üç tekerrürün ortalamasıdır 


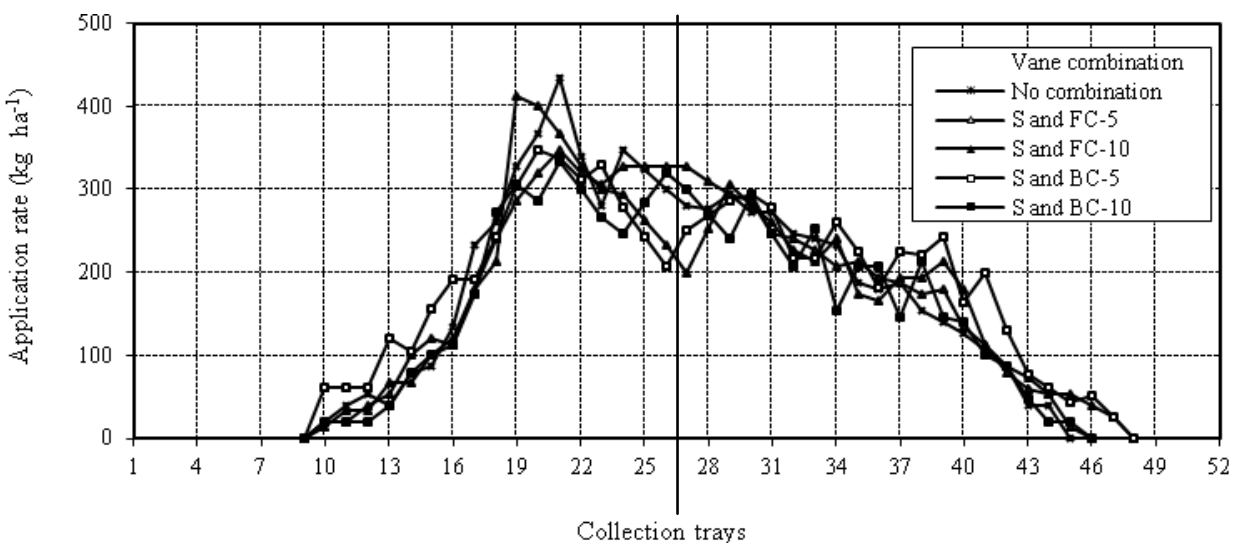

Figure 3-The optimized distribution patterns obtained from the five different combinations of vanes for the orifice diameter of $40 \mathrm{~mm}$. The center of the disc passed midway between the centers of collection trays 26 and 27. Each line is the mean of three replications

Şekil 3-Farklı kanat kombinasyonlarından $40 \mathrm{~mm}$ çapındaki çıkış deliği için elde edilen optimum dağıllım desenleri. Disk merkezi 26 ile 27 numaralı toplama kutularının arasından geçmektedir. Grafik çizgilerinin her biri üç tekerrürün ortalamasıdır

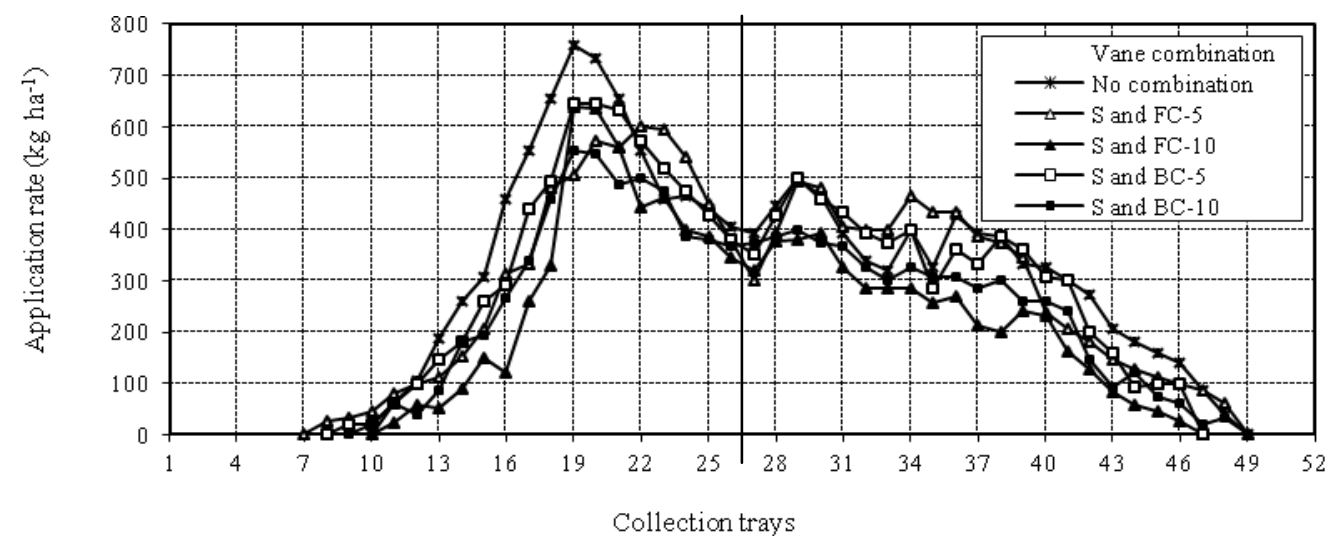

Figure 4-The optimized distribution patterns obtained from the five different combinations of vanes for the orifice diameter of $50 \mathrm{~mm}$. The center of the disc passed midway between the centers of collection trays 26 and 27. Each line is the mean of three replications

Şekil 4-Farklı kanat kombinasyonlarından $50 \mathrm{~mm}$ çapındaki çıkış deliği için elde edilen optimum dağılım desenleri. Disk merkezi 26 ile 27 numaralı toplama kutularının arasından geçmektedir. Grafik çizgilerinin her biri üç tekerrürün ortalamasıdır

results (i.e. the minimum values were closest to $100 \%$ ) for the orifice diameter of 30 and $40 \mathrm{~mm}$. The best minimum value belonging to the orifice diameter of $50 \mathrm{~mm}$ was obtained from the $\mathrm{S}$ and BC-10 vane combination. The S and FC-10 for the orifice diameter of 30 and $50 \mathrm{~mm}, \mathrm{~S}$ and $\mathrm{BC}$ 10 for the orifice diameter of $40 \mathrm{~mm}$ had the worst results (i.e. the minimum values were the lowest). 
The vane combinations including "no combination" also showed significant differences in maximum points in the overlapped patterns. These values also expressed as percentages of the mean rates. The best results in maximum values (i.e., the closest values to $100 \%$ ) obtained from $\mathrm{S}$ and FC-5 for the orifice diameter of 30 and 50 $\mathrm{mm}$. The $\mathrm{S}$ and $\mathrm{BC}-10$ vane combination had the best value along with $\mathrm{S}$ and FC-5 statistically for the orifice diameter of $40 \mathrm{~mm}$. The S and FC-10 vane combination along with "No combination" gave the worst results (i.e., the highest maximum values) in maximum values for all orifices except the orifice diameter of $40 \mathrm{~mm}$. The worst maximum value for this orifice was obtained only from the $\mathrm{S}$ and $\mathrm{FC}-10$ vane combination.

With one type of vanes such as straight, forward curved or backward curved and a single metering port, the pattern will tend to have a peak; however, the peaks will be at different lateral locations for each type of vane. Combining two types will tend to give two smaller peaks rather than on major peak, and thus will make the overall pattern smoother. This effect can be seen in the graphs in Figures $2,3 \& 4$.

The ranges of working width calculated as the minimum and maximum working widths at the CV value lower than only $20 \%$ in overlapped pattern are shown in Table 2 . The more the ranges of working width is wide, the greater tolerance the fertilizer broadcaster will have to external factors such as wind and variations in working width arising from operator errors. The combination consisting of $\mathrm{S}$ and FC-5 vane had the widest ranges for all orifice diameters. These ranges were 2.5, 4.5 and $1 \mathrm{~m}$ for the orifice diameter of 30,40 and $50 \mathrm{~mm}$, respectively.

\section{Conclusions}

Results from this research indicated that the vane combination had an important effect on the distribution uniformity of triple superphosphate for the various flow rates. The fertilizer distribution uniformity became worse as the flow rate of the fertilizer increased for all vane combinations including "no combination". "No combination" had worst distribution uniformity after the combination of straight and forwardcurved-10 vane. Only the straight and forwardcurved-5 vane combination giving the best distribution uniformity for all flow rates of fertilizer provided the acceptable value of $\mathrm{CV}$ for the highest flow rate; hence it can be suitable with the spinning disc broadcasters for the high application rates of fertilizer.

\section{References}

ASAE (1998). Standards S341.2, 1998. Procedure for measuring distribution uniformity and calibrating granular broadcast spreaders. ASAE, St. Joseph, MI

Çarman K (1991). The effect of disc peripheral speed and free radius on the distribution pattern in single spinning-disc type spreader. Selcuk University Journal of Agricultural Faculty 1(2): 75-83

Çarman K (1992). An investigation upon the effect of feeding opening shape on the distribution pattern in disc types spreaders. Selcuk University Journal of Agricultural Faculty 2(3): 29-38

Erol M A \& Özmerzi A (1977). Tek diskli gübre dağıtma makinalarında, iş genişliğinin dağılma düzgünlüğüne etkisi. Ankara Üniversitesi Ziraat Fakültesi Yayınları: 656, Ankara

Olierslagers R, Ramon H \& Baerdemaeker J De (1996). Calculation of fertilizer distribution patterns from a spinning disc spreader by means of a simulation model. Journal of Agricultural Engineering Research 63(2): 137-152

Önal I \& Tozan M (1984). Ege bölgesinde imal edilen tek diskli gübre dağıtma makinaları üzerinde bir araştırma. TZDK Yayın no: 30, Ankara

Önal I (1995). Ekim, Bakım, Gübreleme Makinaları. Ege Üniversitesi Ziraat Fakültesi Yayınları: 490, İzmir

Özbek O, Çarman K \& Şeflek A Y (2006). The effect of free radius and vane position on the distribution pattern in single spinning-disk type spreader. In: Proceedings of the 23th Agricultural Mechanization Congress, 217-221, 6-8 September, Çanakkale, Turkey

Özmerzi A (1974). Ülkemizde imal edilen bazı diskli gübre dağıtma makinaları üzerinde bir araştırma. Ankara Üniversitesi Ziraat Fakültesi Yayınları: 788, Ankara

Parish R L (2001). Pattern uniformity with homeowner rotary spreaders. Applied Engineering in 
Agriculture 17(2): 127-130

Parish R L (2002). Rate setting effects on fertilizer spreader distribution patterns. Applied Engineering in Agriculture 18(3): 301-304

Parish R L (2003a). Comparison of pattern adjustment methods on professional rotary turf spreaders. Applied Engineering in Agriculture 19(5): 535-537

Parish R L (2003b). Evaluation of a homeowner rotary spreader with deflector to close one side of the pattern. Applied Engineering in Agriculture 19(6): 641-643

Srivastava A K, Goering C E \& Rohrbach R P (1993). Engineering Principles of Agricultural Machines. ASAE Textbook Number 6, St. Joseph, Michigan

TÜIK (2011). Statistical database. Available: http:// www.tuik. gov.tr

Yetkin S \& Çarman K (1988). The effect of some vane profiles upon the distribution uniformity. In: Proceedings of the 11th Agricultural Mechanization Congress, 204-213, 10-12 October, Erzurum, Turkey

Yildirim Y \& Kara M (2003). Effect of vane height on distribution uniformity in rotary fertilizer spreaders with different flow rates. Applied Engineering in Agriculture 19(1): 19-23

Yildirim Y \& Ozturk I (2007). Effect of feeding radius on distribution uniformity in single-disc rotary fertilizer spreaders with different flow rates. Ataturk University Journal of the Faculty of Agriculture. 38(1): $65-70$

Yildirim Y (2006a). Effect of vane number on distribution uniformity in single-disc rotary fertilizer spreaders. Applied Engineering in Agriculture 22(5): 659-663

Yildirim Y (2006b). Effect of cone angle and revolution speed of disc on fertilizer distribution uniformity in single-disc rotary fertilizer spreaders. Journal of Applied Sciences 6(14): 2875-2881

Yildirim Y (2008a). Effect of vane shape on fertilizer distribution uniformity in single-disc rotary fertilizer spreaders. Applied Engineering in Agriculture 24(2): 159-163

Yildirim Y (2008b). Effect of side to side spreader angle on pattern uniformity in single-and twin-disc rotary fertilizer spreaders. Applied Engineering in Agriculture 24(2): 173-179 